Љиљана Е. Петровачки

petrovacki@nscable.net

(Филозофски факүлтет - Српски језик и лингвистика, Нови Сад)

\title{
ФУНКЦИОНАЛНО ПОВЕЗИВАЊЕ НАСТАВЕ СРПСКОГ ЈЕЗИКА И НАСТАВЕ КЊИНЕВНОСТИ
}

\section{САЖЕТАК}

У раду се истиче потреба за функционалним повезивањем наставе српског језика са наставом књижевности у циљу успешнијег разумевања и тумачења књижевних текстова и остваривања боље културе изражавања ученика. Као експликација, решавано је неколико лексиколошких и културолошких проблема уочених у структури и семантици лексике у делима из народне књижевности. Њихова решења показују како шири лингвокултуролошки приступи филолошким дисциплинама уопште, имају успешну примену и у дидактичке сврхе.

КЉУЧНЕ РЕЧИ: методика наставе српског језика и књижевности, народна књижевност, лексика традиционалне културе, лингвокултуролошки приступ. 
P еформа високог образовања је у току, доста је урађено на примени Болоњских принципа у универзитетској настави код нас. ${ }^{1)}$ На Филозофском факултету Универзитета у Новом Саду извршена је потпуно нова организација студијских група и наставних предмета и курсева, уведени нови предмети и облици распоређивања наставног градива, нови силабуси и курикулуми. Сви нови предмети и курсеви су и акредитовани. У ком правцу треба да иду даљи кораци, учимо се у ходу, прилагођавајући специфичности својих студијских група захтевима европских стандарда и упоређујући рад других сродних факултета и њихова искуства са нашим. Нове концепције студија српске филологије праве се такође у складу са европским квалификационим оквирима.

Један од проблема који је уочен приликом опште евалуације на нашим студијима је одређена врста дискрепанције између онога што студенти уче на факултету и онога што тражи пракса (нпр. наставничка, преводилачка, лекторско-коректорска). До сада смо углавном обучавали студенте као ће се сви они бавити научноистраживачким радом. Вишесеместрални предмети са испитима на крају одслушаног ${ }^{2)}$ последњег семестра нису били довољно подстицајни за већину студената за континуирани рад. Примена теоријских знања у различитим истраживачким и практичним задацима није била довољно заступљена. Да би се ти недостаци отклонили, осмишљени су предмети и курсеви који захтевају веће ангажовање студената у процесима учења и истраживања и примену њихових знања. Поменућу као пример само оно што је у вези са овим радом. Нпр. у деветом семестру у оквиру изборног курса Функционално ироуиавање лексике уз корелацију са методичким захтевима на курсу Метиоgичке айликаиије, на истом семестру, студенти примењују своја знања из лексикологије у тумачењу непознатих појмова и речи у књижевним текстовима. ${ }^{3)}$ Обједињујући своја лексиколош-

1) Србија је започела реформу 2003. године, прикључивши се Болоњском процесу, како би свој систем високог образовања ускладила са земљама европске уније и осталим земљама Европе. У Болоњском процесу учествује 46 земаља Европе, међу којима је, дакле, и наша земља.

2) Сам квалификатор „одслушани” упућује на пасивну позицију студената у ранијем систему студирања.

3) Треба истаћи да постоји и стална сарадња и добра корелација са супстраним курсевима из књижевности, за ову прилику истичем оне из народне књижевности са Одсека за српску књижевност. ка, лингвокултуролошка и методичка истраживања у оквиру различитих пројеката и семинара, студенти се у тиму са наставницима полако укључују у стручни и научноистраживачки рад и креативно и критички осмишљавају и надограђују филолошке информације у циљу решавања практичних задатака: конкретно у нашем раду самостално откривају значења речи или израза, праве своје специјалне речнике и тиме доприносе разумевању књижевног текста.

У својим ранијим радовима разматрала сам неке проблеме који се јављају у настави српског језика и књижевности у вези са обрадом дела из народне књижевности, најчешће приликом тумачења лексике традиционалне културе. Уочено је да у читанкама, посебно за основну школу, има пуно дела из народне књижевности. У обавезном програму за основну школу предвиђено је да се ученици упознају са најуспешнијим и антологијским остварењима свих усмених књижевних врста и жанрова: од краћих форми, попут народних умотворина типа пословица, загонетки и изрека, до компликованијих епских остварења: народних епских песама и народне прозе, у оквиру које обрађују: басне, бајке, приче, новеле, легенде. Наравно, нису изостављене ни најлепше лирске песме. Та дела одражавају културно-социјалне обрасце и стварност углавном патријархалног друштва и традиционалне културолошке садржаје и репрезентују, наравно, старији језички израз. Стога она обилују архаичном лексиком различитог типа која је неразумљива савременим ученицима, нашим студентима, а често и наставницима. Објашњавање ове лексике захтева значајнију стручну припрему и коришћење разних типова речника од дескриптивних до историјских и различитих специјалних, најчешће речника архаичних терминолошких система. Многе лексеме су и дијалекатски маркиране па је за њихово објашњавање често потребан и дијалекатски речник. Тумачење непознатих речи тако од споредног, постаје важан лингвокултуролошки и методички поступак који треба да објасни тип културе у прошлости и специфичне ситуације, јунаке, њихове односе и целокупни предметни свет дела и на основу тога омогући ученику/ студенту несметану рецепцију.

За овакав озбиљнији филолошки, лингвокултуролошки приступ потребно је оспособити студенте. Раз- 
лике у укупној уметничкој и информативној вредности појединих текстова утичу на одговарајућа методичка решења. Опсег тумачења текстова мора се прилагодити могућностима ученика, али са студентима их треба обрадити свеобухватно у зависности од сложености њихове структуре уз повезивање и поткрепљивање са садржајима из других дисциплина који доприносе исцрпнијој анализи.

Теме, ликови, догађаји из народне књижевности често су далеко од поимања савремених ученика, не само због језичког израза, већ и због специфичног културног кода који треба разумети. Сви смо сведоци да нам се ученици и основне и средње школе, а некада и наши студенти, жале како не разумеју делове текста, или неке ситуације или само одређене лексеме приликом обраде програмски одабраних дела из народне књижевности. Проблеми у рецепцији тих текстова јављају се углавном због великог броја непознатих речи за које они не знају ни сам појам који речи означавају. Објашњавање значења таквих речи, заправо читавог лексичко-семантичког нивоа, захтева један шири лингвокултуролошки приступ јер је већина те лексике често и део регионалне традиционалне народне културе и има доминантну културну компоненту. Тумачење такве лексике тражи један интердисциплинарни приступ и у домену је више антрополошке лингвистике или етнолингвистике. Лексика се приликом семантизације у овом случају мора посматрати у контексту времена, простора и културе, а њеним тумачењем разоткривају се и многе националнокултурне информације.

Показаћемо то на примеру из народне књижевности, на епској песми Почейак буне ирройив gахија, која се обрађује у 8. разреду основне школе у целини, а у Читанци је репрезентована већим одломком. То је уводни, уметнички најснажнији део, у коме народни певач слично славним великим еповима доводи бога, свеце и небо у везу са људским и земаљским збивањима. Сложеност текста на плану значења захтева помно објашњавање великог броја непознатих речи, углавном лексема традиционалне културе и турцизама. У тражењу решења, покушаћемо да представимо оне најбитније водећи рачуна о свим параметрима битним за просторни, временски и културолошки оквир у којем се реч/ текст налази.
У уводном делу песме експресивни ефекти постигнути су описом небеских йрилика у градационом низу и оне су својеврсна упозорења и пророчанства (...земан gо'шо, ваља војевайи... Народни песник као да верује: И небо је на нашој сйрани. То је подстицај за Србе, али и опомена за Турке: ...оно, јолgаш, йо нас go-

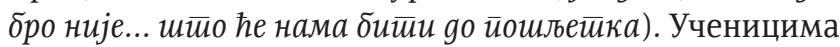
треба објаснити да је овај облик сујеверја и веровања у различита знамења био значајан елемент традиционе културе. Пре сваког важног догађаја у традиционалној култури обраћа се пажња на знаке који му претходе, посебно на „небеске знаке" и појаве. ${ }^{4)}$

Индикативно је и како народни певач временски детерминише ове појаве које су заправо астрономске (помрачење Месеца, Сунца, појављивање комете а које су се збиле у интервалу од 1800. до 1806. године). Најпре, све их је из стилских разлога, (појачавања ефекта ради) песничким поступком анахронизмом сместио у једну годину, 1804, пред почетак Првог српског устанка, да пророчанство буде снажније (...ga се Србљи на оружје gижу.. земан gош'о, ваља војевашии...) а затим сваку небеску йрилику временски везује за неки празник. За нас је културолошки маркиран податак да се време одређује путем верских празника. То је, заправо, и био начин одређивања времена у традиционалној култури. Показаћемо како се овај кулуролошки маркирани податак развија на примерима. Најпре ћемо сагледати категорију времена:

Време:

a) о којем се пева: 1804. година, бурни догађаји који су претходили Првом српском устанку; сеча кнезова и освета дахијама. (Добро би било са ученицима упоредити историјске догађаје у овој години и оно што је реално са описом догађаја у песми, сагледати уметничке поступке народног песника и његову имагинацију у сликању тих догађаја и ликова).

б) Одмеравање времена: Уобичајена, важећа, актуелна календарска подела године у време настанка песме и догађања који се описују, разликује се од наше,

4) Звезде и небеске појаве проучаване су у многим древним културама што је резултирало и наукама, нпр. астрономијом; у старим еповима пева се о звездама, боговима и како они одлучују о судбини људи на земљи и подстичу их на акцију па су и ови стихови, можда, у вези и са тим древним митовима. 
савремене поделе године. У прошлости се година делила на различите начине, између осталог и на два дела, а ти делови су били зима и лето (Гротефенд 2006: 15). Оваква подела године уочава се и у овој песми:

- према подацима из народне песме, може се утврдити да се година дели на два интервала, а интервали су омеђени свецима:

- зима (од Митровдана до Ђурђевдана), лето (од Ђурђевдана до Митровдана). Код Јужних Словена то је основна каленарска граница (подела) пошто се година дели на два полугођа: митровско и ђурђевско (Словенска мийолоїија, 2001).

- Црквени празници - свеци као мера времена долазе до изражаја у нашој народној књижевности, а као илустрација послужиће стихови: Ваку йpву йрилику врі̄още/ Og Трийуна gо Свейоі̄a Ђурђа/ Сваку ноћиу мјесеи, се вайаше... Ови стихови траже коментар. Иако у овом контексту треба најпре објаснити антропоним Трийун, то нећемо учинити овде, него мало касније, а почећемо од хагионима Свети Ђурђе. Значење појма Свеши Ђурђе и значај који он има у нашој традиционалној култури, нећемо наћи у нашим дескриптивним речницима, али се енциклопедијски приказ наше традиције нуди у лексикону Гоgишњи обичаји у Срба и у Словенској митиолоіији (енциклопедијски речник), где се традиција описује из општесловенске перспективе. Поред тога што се из ова два енциклопедијска речника даје и значење и значај овог празника (ови речници не дају облик Свей Ђурђе него његове синониме Ђурђевgан и Георіије св. Побеgоносаи, Свеци: ...cв. Георі̄uјe), у оба извора даје се податак да је Ђурђевдан гранична мерна јединица између зиме и лета, односно да је са Ђурђевданом завршена зима и да је почело лето по традиционалној подели године на два дела, што је резултат византијског рачунања времена; Други појам који треба објаснити у вези са рачунањем времена је хагионим из песме Дмишировgан. Овакав фонетски лик овог хагионима није забележен у ова два речника,

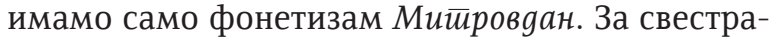
но сагледавање овог појма морамо се послужити истим енциклопедијским речницима традицио- налне културе у којима, између осталог, имамо

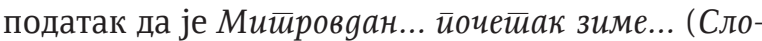

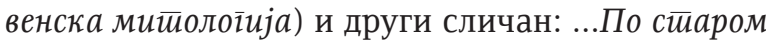
срйском рачунаюу времена, Митировgан... иини крај

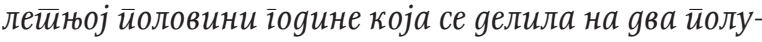
іођа... (Недељковић 1990); У даљој анализи треба свестрано сагледати хагионим Св. Сава који се спомиње у стиховима ірром заїрми на Свейоі̄a Саву/ yсреg зиме каg му време није. Ови стихови се морају лексички денотативно објаснити: Св. Сава је велики православни црквени празник који се празнује 27. јануара. У школама се овај празник обележава као школска слава. Лексеме ірром, заірммиии са аспекта народног веровања траже енциклопедијско лексикографско објашњење: ...ūo нароgном вероваюу, о времену... ако заірми (на Св. Саву) биће великих gоīaђаја у земљи (Недељковић 1990: Св. Сава). Грмљавина на Св. Саву наговештава значајне догађаје за заједницу која га слави. Трийун, овај антропоним у песми је употребљен у значењу ха-

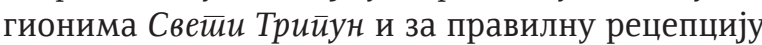
треба га детаљно објаснити (...у йрољеће на Свейої Трийуна (14. фебруара)). И овај стих захтева објашњење из данашње перспективе на просторном и временском плану. Просторно, замена ф са $\bar{u}$ у овом хагиониму упућује на ијекавско порекло песме или певача, чему треба посветити пажњу на екавском подручју на којем се ради из анализиране читанке. Овај хагионим никад нема овакав фонетизам на екавском терену на којем замену ф са $\bar{u}$ имамо само у општепознатим речима (пасуљ, пост). Просторна, дијалекатска замена ф са в (Трифун: Тривун) такође указује на наше западне (ијекавске) крајеве из којих је певач пореклом, уколико ова замена није резултат накнадне интервенције да би песма била у одговарајућем дијалекатском изразу. Време: ...у йрољеће на Свейой Трийуна... Смисао овог стиха може се схватити ако се обавестимо о значају овог хронотопа. На овај црквени празник код балканских Словена обележаван је почетак аграрног циклуса (Словенска мийолойија: Тривундан), што постаје још јасније када се има у виду да је на овај празник у прошлости требало 
пре подне сејати озимо, а после подне јаро жито (Недељковић 1990: Тривундан). Из овог стиха се посредно потврђује веровање о граници између зиме и лета/ пролећа на св. Трифуна јер је за пролеће било везано сејање јарих усева. (Гранично време између зиме, која се завршава, и летњег периода који почиње од овог датума рачуна се и по средњевековном немачком календару (Гротефенд 2006)). Данас је св. Трифун код нас виноградарска и винарска слава. То је званично почетак резања винограда и почетак нове виноградарске сезоне. Још један хагионим, који се појављује у стиховима, тражи објашњење: Часне вериге (...Сuну муюа на Часне вериїе...). Празник Часне вериге познат је у данашње време само у уским православним црквеним круговима, детаљно је обрађен само у Гоgишњим обичајима у Срба, тако да се овај извор мора обавезно консултовати у обради ове песме. Основно значење овог хагионима је: Часне вериге (црквени празник, 16/ 29. јануар), муње нису оубичајене у то време, што се опет схвата као знамење. Дан празновања верига (ланаца, окова) Светог Петра, које су исцелитељске ...йразноване су у нароgy og ірома (Недељковић 1990: Часне вериге). Даљом анализом стиха, узимајући у обзир денотативно значење овог појма, можемо се позабавити везом између севања муње на овај дан и празновања овог свеца og ірома. Временска, а и културна удаљеност савременог света од културног кода представљеног у песми, тражи додатна обавештења о значењу и значају овог празника и његовом месту у структури песме. Једно од објашњења могло би бити у смислу тумачења симболике: Можда муња која обасјава иасне вериіе , тј. ланце светог Петра, симболизује наговештај да ће се прекинути ланци ропства српског народа. Маркирање дана у години према именима светаца, значење наведених хагионима и значај у годишњем циклусу и у народној традицији, као и веровања везана за поједине хагиониме, видимо, битна су за разумевање песме.

б) када се пева: неколико година после стварних догађаја (није тачно установљено када је Вишњић испевао ову песму: да ли првих дана устанка, док је још био у Босни, или 1809. када је прешао у Србију, по неким претпоставкама, учинио је то тек после 1813, пошто је прешао у Срем).

в) временски след догађаја: различит у стварности и у песми. (Ученицима указати на песничку слободу и однос уметничке истине према историјској).

\section{Простор:}

а) о којем се пева: земља Србија. Треба објаснити шта овај синтагматски спој значи реално у време певања песме, а како је представља певач (земља Србија, на коју певач мисли док пева, у ствари је у оно време био Београдски пашалук); пашалук, област као подручна територија једног паше;

б) места дешавања из одломка песме: Биоград/ Београд; У време када је испевана песма, Београд је био под Турцима и био је турска тврђава и град у којој су заповедници биле дахије. Биоіраg: оваква замена јата са $u$ је у складу са ијекавцем певачем, а званично је и у време певања ове песме назив имао екавску форму; Биоіраgаu, ијекавски облик етника (Београдац) у складу је са ијекавским изговором певача, а овде нашу пажњу заслужује форма етника која данас није позната кад је у питању овај хороним, данас је само Београђанин. Сйамбол-кайија, једна од београдских врата/ капија на коју се улазило/ излазило, где је почињао пут према Цариграду (Стамболу); Небојша кула Јакшићева, кула на Дунаву, испод београдског града, Калемегдана, коју су по предању, саградили српски феудалци браћа Јакшићи у другој половини 15. века. Упечатљива је у песми сцена на врху Небојше куле, где дахије хидроманским прорицањима у стакленој тепсији пуној воде из Дунава илеgају своју судбину; кнежина, област у којој влада од Турака изабрани кнез, у којој је сиро$\bar{u} u њ a$ paja, становништво Београдског пашалука (...Он Туриину не gа у кнежину/ Каg Туриина у кнежини нађе/ Тойузом му ребра исиребија...); нахије, области, управне јединице (по турском систему поделе државе на мање јединице), нпр. Ваљевска нахија: (...Поћи ћемо из на-

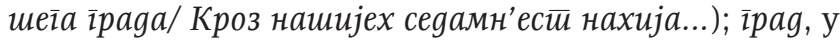
прошлости тврђава.

Све ово су културолошки маркиране информације на које треба обратити пажњу приликом одређивања времена и простора у песми. Оне доприносе стварању 
представа о типу културе: могу дочарати реални живот човека из прошлости, на почетку 19. века у Србији (сељака - раје, кнежева, јунака, дахија, Турака). Анализирајући све ове културеме, као и песму у целини, уочава се специфичан тип патриотске ратничке патријархалне културе српског народа.

Са ученицима ћемо уочити и велики број турцизама у песми и објашњавати њихово значење, али овом приликом се нећемо њима бавити. (Само констатујемо да су у нашој традиционалној култури турцизми различитог порекла веома заступљени).

Чувена народна балада Хасанаїинии, која је Европи открила нашу народну поезију, ${ }^{5)}$ тешко се може тумачити из данашњег времена. Савремени ученик не може разумети поступке главних јунака без познавања обичаја њиховог времена и средине, њиховог културног кода. Старинска схватања и норме патријархалне етике далеко су од поимања наших тинејџера, те им најпре треба путем различитих текстолошких коментара појаснити друштвене и историјске околности и обичајне законе. ${ }^{6)}$ Данашња деца очекују од Хасанагинице да се бори за правду, за своју децу, за себе, а не само да се слепо повинује наређењима. Са таквим ставом они не могу довољно да саосећају са њеном трагичном судбином. Културне разлике и различита друштвена правила чине суштину неразумевања песме, те је неопходно премостити те разлике поредећи кодексе два времена.

Компаративне и психолошке анализе морају да узму у обзир различите норме понашања, веровања, начине општења, системе вредности и све оне животне обрасце који делују на понашање људи, читав поглед на свет (Бугарски 2006: 35). Тек тако ће моћи да се уоче неписани патријархални закони који су били немилосрдни према жени и какав је то Хасанагини-

5) Хасанаі̄uнииу је објавио и превео на италијански у свом путопису Алберто Фортис (Viaggio in Dalmazia, Venecija, 1774.) Од тада преведена на низ европских и ваневропских језика и инспирисала многа наша и страна уметничка дела.

6) Након читања песме и проверавања ученичких доживљаја, неки ученици рекли да им песма делује „помало бесмислено”. Веома је трагична, али не схватају зашто Хасанагиница није ишла да посети рањеног мужа, зашто је муж изгони из куће, зашто је она њега послушала, и одмах отишла, зашто је брат тако брзо преудаје... и др. Управо је због тога неопходно објаснити све те социокултуролошке проблеме. чин стид због којег није отишла да посети рањеног мужа. Он је проистекао из традиције у којој жена није смела ни на који начин да изрази љубав према мужу, па чак ни име свога мужа гласно да изговори. Стид је постао и трагична кривица младе Хасанагинице. Зашто га Хасанага није препознао, разумео и поштовао, може да буде једно од кључних проблемских питања које ће ученици решавати. Истраживачким читањем и праћењем својих уметничиких доживљаја уочаваће значајне појединости, ситуације, поступке и поруке. У зависности од узраста ученика, постављаће се образовни, васпитни и функционални циљеви. ${ }^{7)}$

У својој методичкој студији о Хасанаі̄иниии Милија Николић препоручује да се у обради овога дела примене проблемски приступи и истакао је неколико проблема за чије решавање је потребно познавати социокултурни контекст и положај жене у патријархалном друштву (посебно у муслиманској средини). Да би ученици могли успешно да реше литерарне проблеме и недоумице, припремљени су конкретни задаци за истраживачко читање и стваралачко и критичко мишљење (Николић 1999: 564). Веза између лексичког и културолошког нивоа песме, заправо познавање њеног културног оквира веома су важни најпре за добру рецепцију и касније школску интерпретацију. Из примера истраживачких задатака се може закључити да је препорука да се о књижевном делу не предаје већ да га ученици истражују и тумаче и да је њихова ментална активност усмерена према самој песми као извору сазнавања. Интердисциплинарни приступ у коме се сједињују знања из историје, религије, социологије, народних обичаја и др. могу довести до спознаје суштине. Систем вредности и културни код који песма подразумева у вези је и са непознатим лексемама. Стога се оне тумаче на основу дефиниција у РMC. ${ }^{8)}$ У наставку је дат уазбучен попис речи које су ученицима биле непознате, са неопходним објашњењима за разумевање:

7) У ранијим наставним програмима Хасанаі̄иница је била предвиђена за обраду у завршним разредима основне школе, када је требало да се ученици упознају са баладом као лирско-епском врстом, а у новим курикулима је, с правом, укључена у средње школе. Трагична породична тематика разумљивија је старијим ученицима.

8) РМС - Реиник срйскохрвапискоі̄ књижевноі̄ језика, 1967-1969, 1-3 Нови Сад, Загреб, 1971-1976, 4-6. Нови Сад. 
aīa, тур. - 1. а. власник земље (у некадашњој Турској) коју је други обрађивао, б. титула код муслимана: господин, газда (додаје се иза имена) 2. војни старешина у Турској. У вези са лексемом ага (Хасанага) поставља се питање о положају и статусу тог лика и може се сагледати како је девојка из беговске куће удата за агу. Поред објашњења из дескриптивног речника, треба нагласити да је бег по статусу виши од аге, али да је без обзира на порекло Хасанагиница као и све жене у исламском свету потпуно обесправљена.

бабо, тур. - а. отац, поочим; дед б. свекар, таст. У конкретном примеру ова лексема има значење отац.

бет̄, тур. - муслимански племић, велики поседник у турском царству

бешика, тур. - колевка Ово објашњење није довољно јер већина ученика није видела колевку, познато је да мала деца одавно спавају само у креветићу. Ученицима се може објаснити да ови предмети имају исту употребну вредност, али да се у песми појављује бешика(колевка) да означи да је реч о недавно рођеном детету од кога мајка мора да се одвоји, тако да њен бол бива још већи.

ірести $u$, заст. песн. - ићи

gauи, тур. - ујак

gвор, нар. песн. (понекад мн.) - дом, кућа уопште каga, хип. од кадуна

каguјa, тур. шеријатски судија. Објашњење није задовољавајуће јер ученици не знају каква све учења међу муслиманима постоје, те разумеју да је то некакав судија, али не знају какав му је социјални статус.

каяуна, тур. - угледна жена, госпођа

кула, тур. - 1. а. високо уско здање, обично округлог или четвртастог облика који стоји одвојено или као део веће грађевине, тврђаве 2. покр. камена кућа, обично већа, масивнија

малахно, прил. песн. - мало

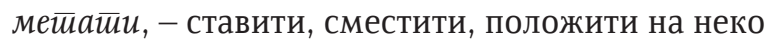
место

мучайu, - не говорити, не издавати гласа од себе, ћутати иенцер, тур. - прозор

убошки - убог, бедан

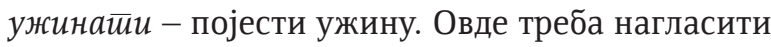
да се мисли на глагол јести, јер реч ужина данас нема оно значење које је имала у прошлости, као ни глагол од ње изведен.

уйу $\bar{u}$, прил. покр. - одмах, сместа

$x a j a \bar{u} u-$ марити, обраћати пажњу, бринути се

хаљине - мушко одело састављено од више делова; сви делови женске одеће за једну прилику. Ученицима је ова лексема позната у значењу женског одевног предмета из једног дела, али овде има застарело значење и односи се на одећу уопште, па чак може да се односи и на постељно рубље. Могуће је чути у говору старијих особа у неким дијалектима.

чоха, тур. - фабричка творевина (ређе домаћа), врста меке и чврсте вунене тканине

Употреба речника за ученике је веома корисна. Они се тако конкретно уверавају да су речници ризнице података из свих животних области. Откривање семантике непознатих речи за њих постаје занимљив истраживачки посао. На тај начин и лексикологија добија у настави своју практичну примену, што је изузетно важно јер се овој дисциплини у науци о језику, па и у средњошколској настави поклања мало пажње. Учинак који је постигнут је и у томе што је остварено функционално повезивање наставе језика и наставе књижевности, што је као крајњи циљ довело до бољег разумевања предметног света песме. Тек пошто упозна значење сваке појединачне речи у контексту и контекст сам, ученик може да замисли и доживи уметничке представе песме и да је заједно са наставником тумачи.

Наставна пракса је показала да се ученици нерадо баве народном поезијом управо зато што је не разумеју довољно. Стога су у раду понуђени методички модели који могу бити примери како објашњавати непознате лексеме из народне традиције. Определила сам се за народне песме које ученицима проузрокују највише проблема: Почейак буне йройив gахија и Хасанаїинииу. Лексеме су анализиране као културеме јер је требало објаснити и социокултурни контекст. Желећи да ука- 
жем на потребу усмеравања веће пажње на семантичку компоненту језика књижевног дела (која је прилично занемарена у нашим лингвистичким истраживањима), настојала сам да покажем како се функционално могу повезивати лингвистичка и књижевнонаучна испитивања у интерпретацији одабраних програмских књижевних дела. У многим случајевима, истраживања треба поставити још шире, интердисциплинарно.

\section{И з в о и :}

- Бајић, Љ. и Мркаљ 3. (2010). Чишианка за осми разреg основне школе. Београд: Завод за уџбенике и наставна средства.

- Николић, Б. и Милић Љ. (2010). Читианка са кюижевноиееоријским йојмовима за ирви разреg среgюих школа. Београд: Завод за уџбенике и наставна средства

\section{Провера лексичкеграђе:}

- РМС: Речник срйскохрвайскої књижевной језика 1967-1969. 1-3 Нови Сад, Загреб, 1971-1976, 4-6 Нови Сад.

- Једнотомник МС Речник срйскоїа језика. 2007. Нови Сад: Матица српска.

- РСАНУ Реиник срйскохрвайскої књижевної и народної језика. 1959- . Београд: САНУ

- Караџић, В. Ст. (1852). Срйски рјечник. Беч: Штампарија јерменског манастира.

- Словенска митиолог̃ија, енииклойеgијски речник (2001). (ред. Толстој, С. М. и Раденковић, Љ.) Београд: Zepter Book World.

- Шкаљић А. (1965). Туриизми у срйскохрвайском језику. Сарајево: Свјетлост.

\section{Л И Т Е Р А Т У Р А}

- Гротефенд, Х. (2006). Рачунане времена у немачком среgнем $u$ новом веку. Нови Сад: Стилос.

- Бугарски, Р. (2002). Култура и језик. Сусрей кулйура. Нови Сад: Филозофски факултет.

- Кемура И. (1980). муслиманска имена и юихова значења, Сарајево, Старјешинство Исламске заједнице Босне и Херцеговине

- Кончаровић, К. (2006). О једном лингвокултуролошком моделу дескрипције и дидактичке презентације лексике. Научни сасиианак слависйа у Вукове gане. бр.36/ 1. Београд: МСЦ.

- Недељковић, М. (1990). Годишњи обичаји у Срба. Београд: Вук Караџић.

- Николић, М. (1999). Обрада народне баладе Хасанагиница: проблемски приступ. Мейоgика насйаве срйскої језика и книжевносии. Београд: Завод за уџбенике и наставна средства.

- Петровачки, Љ. (2006). Читанка, мозаик стаза, лица,

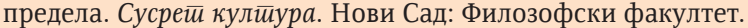

- Петровачки, Љ.; Недељков, Љ. (2008). Лингвокултуролошка и методичка тумачења лексике традиционалне културе у читанкама. Зборник за филолоі̄ију и линівисииику. бр.50. Нови Сад: Матица српска.

- Петровачки, Љ. (2008). Културолошке димензије читанки.

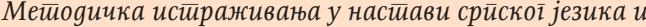
књижевности. Нови Сад: Филозофски факултет.

\section{Ljiljana E. Petrovački}

\section{FUNCTIONAL CONNECTING OF TEACHINGS OF SERBIAN LANGUAGE AND LITERATURE}

\section{Summary}

In this paper, we underline the need for functional connecting of the teachings of Serbian language and literature with the goal of more succesful understanding and interpretation of the literature and students' improved culture of expression. For explicational purposes, we solved several lexicological and cultorological problems observed in the structure and the semantics from the pieces of the folcloric literature. Their solutions show how broader linguo-culturological approaches to philological disciplines in general have successful application in didactical purposes as well.

Key words: teaching of Serbian language and literature, traditional literature, lexis of traditional culture and literature, linguocultural approach. 